\title{
Towards an African Christian Theology of the Blood of Jesus Christ
}

\begin{abstract}
This article proposes an African Christian theology of the blood of Jesus Christ which biblically explains and answers experiential questions raised in African historical and sociocultural contexts. Through the process of conceptual analysis, articles on animal sacrifices in African Traditional Religions and articles in the theological fields of Biblical Theology and Systematic Theology are interrogated to propose an African Christian Theology of the blood of Jesus Christ. The proposed African Christian Theology of the blood of Jesus Christ posits that God acts on the basis of the vicarious shedding of the blood of Jesus Christ to incorporate believers into a Father-Child relationship that grants the believer access to a special divine benevolence. God's benevolence is the means by which the believer experiences the transformative power of God that leads them to progressively experience improvements for their holistic well-being while anticipating the return of Jesus Christ to reinstate a perfect holistic well-being for God's people.
\end{abstract}

Keywords: The blood of Jesus, Animal sacrifices, and African Christian Theology.

\section{INTRODUCTION}

The African pre-Christian worldview influences the African Christian formulation of the theology of the blood of Jesus Christ. The shedding of the blood of Jesus Christ is considered in the Christian faith to be the peak of the mission of God for the redemption of God's creation. The need for the formulation of African Christian theologies on specific biblical themes that are sensitive to African cultures without contradicting biblical truths has been recognized and pursued by several African Christian theologians from the middle of the 1960 s. $^{2}$ Theological formulations guide cognitive comprehension, affective commitment, volitional choices, and orthopraxis of the faith.

This article answers the question: What form of an African Christian theology of the blood of Jesus Christ resonates with the universal divine message that the biblical theme of the shedding of the blood of Jesus Christ communicates?

Contemporary African Christian theology of the blood of Jesus Christ posits that the shed blood of Jesus Christ has inherent divine power that can be invoked by faith to address the challenges of life that contend with the holistic well-being of human beings. ${ }^{3}$ This article proposes an African Christian theology of the blood of Jesus Christ which posits that the shed blood of Jesus Christ serves vicarious purposes for the forgiveness of sins, incorporation of believers into a Father-Child relationship which grants the believer special access to a special divine benevolence as a means of experiencing the transformative power of God.

\section{The Founding Assumptions for the Article}

Since the shedding of the blood of Jesus Christ is a core theme in the biblical metanarrative, it is to be expected and assumed, that an African Christian theology of the blood of Jesus Christ has spontaneously evolved in the course of

\footnotetext{
Stephen Z. Yashim, PhD (Intercultural Studies/Missions - ECWA Theological Seminary, Jos, Nigeria) is an ordained Minister of the Nigerian Baptist Convention serving as pastor of New Estate Baptist Church, Bwari, Abuja. He is a Part-time Lecturer at the Baptist Theological Seminary, Kaduna, and recently with the ECWA Theological Seminary Jos (Abuja Center). E-mail: yashimsz@yahoo.com.

Emmanuel Umar, $\mathrm{PhD}$ (Historical Archaeology - Sichuan University, Chengdu China) is an ordained Baptist Minister of the Nigerian Baptist Convention serving currently as a Part-time Lecturer of Adeleke University Osun, Osun State, Nigeria. E-mail: emmanuel_umar@yahoo.co.uk.

2 Ezekiel Emiola Nihinlola, Human Being, Being Human: Theological Anthropology in the African Context. Ogbomoso: Nigerian Baptist Theological Seminary, 2018, 13.

3 Gideon Yohanna Tambiyi, The African Church Under Fire: Problems and Prospects. Kaduna: Tubase Prints and Publishing, $2014,162$.
} 
the growth of Christianity in Africa. The theology of the blood of Jesus Christ is the expression of the conceptual understanding of the biblical theme of the blood of Jesus Christ.

It is assumed that the pre-Christian African worldview on animal sacrifices has influenced the development of contemporary African Christian theology of the blood of Jesus Christ. Tite Tenou and Paul Hiebert, argue that there are no culture-free and history-free theologies because "all theologies are embedded in histories and worldviews that shape the way they see things." ${ }^{\prime 4}$ Theology impacts how Christians live. Because of its impact on the way those who subscribe to it live, contextual interpretations of biblical notions need to be critically evaluated and compared with interpretations of the same notion in other contexts in order to eliminate inappropriate biases. ${ }^{5}$ The purpose of this article is to propose and disseminate an African theology of the blood of Jesus Christ that is biblically rooted, contextually relevant and meaningful, and impacting the praxis of the Christian faith in Africa. The African theology is developed through critical analysis and integration of the African notion of animal sacrifices, animal sacrifices in the Old Testament, and the New Testament's interpretation of animal sacrifices.

\section{DELIMITATION AND METHODOLOGY}

The data examined and evaluated in this article is limited to the review of articles written on animal sacrifices in African Traditional Religions (ATR) as well as articles on animal sacrifice in the Old Testament and on the shedding of the blood of Jesus Christ in the New Testament written by scholars in both Systematic and Biblical theologies. The focus is on the objective and subjective sources of developing theology. The Bible is the objective source and experience is the subjective source of theology arrived at through dialectical interaction of both under the guidance of the indwelling Holy Spirit. ${ }^{6}$ ATR worldview on animal sacrifice is the subjective source and the Bible is the objective source for developing an African Christian Theology of the blood of Jesus Christ.

Conceptual analysis is the method applied in this article. Conceptual analysis is a type of content analysis used to determine the presence of certain words, themes, or concepts within a given qualitative data. ${ }^{7}$ Conceptual analysis can be used to identify the intentions, focus or communication trends of an individual, group or institution. ${ }^{8}$

The object of content analysis can be all sort of recorded communication. Philipp Mayring, categorizes levels of content into two: themes and main ideas of the text as primary, and context information as latent content. ${ }^{9}$ The biblical theme of the blood of Jesus Christ is chosen for this study. The source of data for analysis and interpretation are articles on animal sacrifice in ATR and evangelical literatures in the theological fields of Systematic Theology and Biblical Theology.

Christianity in Africa is the product of Euro-American missionary endeavors. There are significant changes from the Euro-American missionary Christianity introduced in Africa. An evaluation of the Euro-American Christianity introduced in Africa indicates that there is need "to strike a balance between the dividends of the Missionary West and the contextualization by the African impute." ${ }^{\prime 10}$ The development of an African Christian theology of the blood of Jesus Christ is a means of gaining additional insight concerning the biblical theme of the blood of Jesus Christ.

\section{Benefits of Developing an African Theology of the Blood of Jesus Christ}

Three key benefits of developing an African theology of the blood of Jesus Christ are outlined below. First, the discussion proposes a modification and the deepening of unique features of contemporary African Christian theology of the blood of Jesus Christ. Timothy Palmer, posits that the African culture can be a source of theology because the African culture, for example, has a deep understanding of the spiritual world. Palmer however cautions against the use of culture as a primary source of theology to avoid the danger of syncretism. ${ }^{11}$ It modifies the overt application of cultural beliefs for the purposes of the shedding of animal's blood for sacrifices that go beyond God's intent and purposes of the shedding of the blood of Jesus Christ in God's mission. It deepens the value of the blood of Jesus Christ in the light of cultural beliefs for the purposes of the shedding of animal blood for sacrifices.

\footnotetext{
4 Tite Tienou and Paul G. Hiebert, "Missional Theology" in The Gospel in Human Contexts: Anthropological Explorations for Contemporary Missions edited by Paul G. Heibert. Grand Rapids, Michigan: Baker Academic, 2009, 42.

5 Paul G. Hiebert, "The Gospel in Human Contexts: Changing Perceptions of Contextualization"” in Missionshift: Global Mission Issues in the Third Millennium" edited by David J. Hesselgrave and Ed Stetzer. Nashville, Tennessee: B \& H Publishing Group, $2010,97$.

Timothy Palmer, Christian Theology in an African Context, (Bukuru: African Christian Textbooks, 2015), 7-8.

Columbia University Mailman School of Public Health, “Content Analysis” Retrieved from www.mailman.columbia.edu accessed June 5, 2019; Philipp Mayring, "Qualitative Content Analysis" in Forum: Qualitative Social Research, 1:2, Art 20, June, 2000, accessed June 5, 2019. Retrieved from www. qualitative-research.net.

8 Columbia University Mailman School of Public Health, "Content Analysis"

9 Mayring, "Qualitative Content Analysis."

10 Moses Audi, "Living with Inherited Denominations: An African Perspective" in Indigenization of the Church in Africa: The Nigerian Situation. Edited by A. A. Akande, M. Audi and O. B. Oladejo, (Ogbomoso: NBTS, 2012), 169-170.

11 Palmer, Christian Theology in an African Context, 8.
} 
Second, syncretistic conception and misapplication of the biblical doctrine on the blood of Jesus Christ can be avoided. It has been stated earlier that over three decades ago, Kato alleges syncretism to be a challenge to Christianity in Africa and that the spiritual battles Christianity in Africa will fight will be largely on theological grounds. While it is the accepted norm in evangelical Christianity that biblical revelation is the standard against which all Christian practices are measured yet the practices are themselves based on how the biblical text and its message has been understood. Thus, the proposed African Christian theology of the blood of Jesus Christ is an attempt to contribute to victory over contradictory beliefs and practices in worship and life arising from syncretistic conception and misapplication of the biblical doctrine arising from the blood of Jesus Christ theme in the biblical metanarrative. The outcome facilitates the development of a biblically balanced, culturally meaningful, and contextually relevant theology and a transformed worldview of African Christians on the biblical concept of the blood of Jesus Christ. The biblically transformed African Christian worldview on the blood of Jesus Christ becomes the focal point that influences African Christians' cognitive appreciation of biblical truth concerning the person and work of Jesus Christ, affective commitment to the person of Jesus Christ out of love, and volitional decisions and moral choices for the purpose of living in holiness. Living in holiness is the visible expression that communicates the power of the shed blood of Jesus Christ.

Third, the discussion contributes to the discourse on the development of African Christian theology of biblical themes. This evaluative examination of and proposal for an African Christian theology of the blood of Jesus Christ is part of the ongoing scholarly quest for the development of African Christian Theology that is biblical, contextually relevant and meaningful. The next section discussed syncretism which is considered as a theological threat to the development of African Christian theology.

\section{Syncretism as a Theological Threat in Africa}

There is need for developing contextual theologies that are biblical and culturally sensitive to guide African Christians' cognitive comprehension, affective commitment, volitional choices, and orthopraxis of the faith. The Encyclopedia Britannica describes religious syncretism as the fusion of diverse religious beliefs and practices. ${ }^{12}$ Theological syncretism is characterized by the uncritical integration of elements of traditional beliefs with biblical doctrines. ${ }^{13}$ Contextual theologies need to be developed devoid of syncretism.

Keith Ferguson states that the process of contextualization seeks to clearly communicate God's eternal truth in another cultural worldview in an understandable way whereas syncretism is the outcome of the merger of two worldviews into one new worldview. ${ }^{14}$ Syncretistic Christianity is the product of mixing the biblical gospel message with something else to produce a different gospel. ${ }^{15}$ Hiebert, describes syncretistic Christianity as Christo-paganism "which has the form of Christianity but not its essence." 16

Syncretism erodes biblical fundamentals and promotes universalism that undermines the unique universal biblical message of the gospel. ${ }^{17}$ The Euro-American missionaries who facilitated the establishment of Christianity in the nineteenth and twentieth centuries were not adequately equipped on how to appropriately address challenges they faced in Africa that made the process of developing theology in Africa prone to syncretistic tendencies.

Moses Audi, outlines thirteen challenges the Euro-American missionaries faced; four of which include:

1. The missionaries' inability to distinguish cultural differences from cultural depravity;

2. Consequent difficulty in distinguishing cultural imperialism from doctrinal or structural truths because the missionaries thought it is only the cultures of Africans that needs transformation;

3. The assumption that culture change is equal to culture transformation therefore the missionaries pursued culture change through social projects like schools to accompany the declaration of the gospel;

4. The missionaries' inability to understand the happenings in African cultural contexts and the expected responses from both the missionaries and the African respondents therefore the missionaries imposed their theologies (from above) rather than developing contextual theologies (from below). ${ }^{18}$

The Euro-American missionary theological formulations that guide African Christian practices did not offer answers to the concrete questions raised by their day to day experiences. Adelani Akande, citing Andre Karamaga, posits that African Christians still live according to the traditions in their villages or neighborhoods while the missionary Christianity introduced in their historical and socio-cultural contexts offer "no answer to the concrete problems of day

\footnotetext{
12 "Religious Syncretism" in Encyclopedia Britannica, accessed June 19, 2020. www.britannica.com/topic/religious-syncretism

3 Gailyn Van Rheenen, Communicating Christ in Animistic Contexts. (Pasadena, California: William Carey Library, 1991 ), 42.

14 Keith Ferguson, “Contextualization \& Syncretism” in International Journal of Frontier Missions. 23:3 Fall 2006, 127-133, accessed June 7, 2019.Retrieved from www.gospelrenewal.com/blog/2012/04

15 Ed Stetzer, "Avoiding the Pitfall of Syncretism," accessed June 7, 2019 www.christianitytoday.com/edstetzer/2014/june/avoiding-pitfall-of-syncretism

16 Paul G. Hiebert, Transforming Worldviews: An Anthropological Understanding of How People Change (Grand Rapids, Michigan: Baker Academic, 2008 ), 11.

7 Akande, "The Role of Theological Education," 165.

8 Audi, "Living with Inherited Denominations", 173-179.
} 
to day existence." 19 Therefore, it is necessary to develop contextual Christian theologies that guide African Christian orthopraxis.

\section{Developing African Christian Theologies}

Christian theology is the human contextual understanding of God's universal message revealed in the biblical metanarrative. Tienou and Hiebert, ${ }^{20}$ and Samuel Waje Kunhiyop ${ }^{21}$ agree that Christian theology is the human intellectual and spiritual quest to find biblical answers to questions raised by their contextual experiences. Hence theology is shaped by the social, cultural, psychological, and historical context of the interpreters of biblical texts. In the process of developing a contextual Christian theology, the Bible is the primary objective source and the Holy Spirit is the subjective guide in the mind and heart of the Christian.

John S. Mbiti, Bolaji Idowu, Byang Kato, Tite Tienou, and Osadalor Imasogie are some African Christian scholars with high academic skills and adequate knowledge of their culture and disciplines. These scholars have provoked interest in doing Biblical Atonement and its Significance for the Faith of Africans in the $21^{\text {st }}$ Century Ministry African contextual theology. ${ }^{22}$ It is acknowledged that efforts aimed at contextualizing theology are accompanied by insipient dangers such as syncretism.

Byang Kato, posits that "Biblical Christianity in Africa is being threatened by syncretism, universalism, and Christo-paganism" and that Christianity will "fight spiritual battles largely on theological grounds." 23 Therefore, since it is assumed that an African Christian theology of the blood of Jesus Christ has evolved in the course of time, it is considered necessary to propose a theology of the blood of Jesus Christ that eliminates socio-cultural biases to avoid a syncretistic theology.

The development of theology is based on two assumptions. First, it is assumed that the biblical metanarrative is the divinely inspired description of the mission of God in God's creation for God's intent and purposes. Palmer, citing Osadolor Imasogie, posits that "the primary objective source of theology is Scripture," it is the primary objective means by which the Holy Spirit continues to disclose God to humans. ${ }^{24}$ The divine words, works, and wonders recorded in Scripture are considered to be the expression of the mission of God. The mission of God is revealed in different historical contexts and through the record of the mission of God, God's universal message for all human beings regardless of their historical context is revealed.

Second, it is assumed that God's universal message can be subjectively understood from the conceptual perspective or conceptual horizon of the recipient of the message in historical contexts which are different from the historical context in which it was revealed. However, the subjective understanding of the God's universal message requires the help of the Holy Spirit who is the primary subjective guide for developing theology. ${ }^{25}$ "Church's dogmatic tradition, human culture and world view, and human historical situations which God uses as occasions for our apprehending His self-disclosure" 26 are other secondary sources of theology. Imasogie, however, cautions that "these secondary sources must not be overemphasized." ${ }^{27}$ Hence, over emphasis or over- dependence on conceptual perspective or conceptual horizon of the recipient of the message in their historical contexts (secondary source of theology) without the help of the Holy Spirit (primary source of subjective theology) could cause the message to be misunderstood and therefore misapplied to produce syncretistic Christian beliefs and practices. Syncretistic Christian beliefs and practices contradict the intent and purpose of God as revealed in the biblical metanarrative.

Therefore, Christian theology is the outcome of a process of epistemological interaction that depends on the help of the Holy Spirit between themes in the biblical metanarrative and themes within the context of human experience from within the historical worldview of the believers. ${ }^{28}$ Hence Christian theology is developed through the application of the contextual epistemological frameworks, while depending on the help of the Holy Spirit, to interpret the biblical universal message revealed in the biblical metanarrative. Also, Christian theology impacts Christian praxis in the context it is developed.

The revelation of God as recorded in the biblical metanarrative is never in a vacuum, it is always in a particular historical context of culture and philosophy. Hence theology is best developed through the application of an eclectic

\footnotetext{
19 Adelani Akande, "The Role of Theological Education in Contextualisation" in Indigenization of the Church in Africa: The Nigerian Situation edited by A. A. Akande, M. Audi, and O. B. Oladejo. (Ogbomoso: NBTS, 2012), 152.

20 Tienou and Hiebert, "Missional Theology," 38.

1 Samuel Waje Kunhiyop, African Christian Theology. (Nairobi: Hippo Books, 2012), 2.

Akande, "The Role of Theological Education", 160.

Byang Kato, Biblical Christianity in Africa, (Achimota, Ghana: Africa Christian Press, 1985), 11.

Palmer, Christian Theology in, 7. Palmer cited Imasogie.

Ibid.

Ibid.

Ibid, 7-8.

Nihinlola, "Human Being, Being Human," 15.
} 
methodology that incorporates elements of other fields of human inquiry. An eclectic methodology is "appropriate for the attempt to investigate an issue comprehensively with regard to the major sources for the formulation of Christian theologies: biblical exposition; social and cultural contexts; human, religious and spiritual experiences; philosophy and nature." ${ }^{\prime 29}$ Since the development of theology is the product of epistemological interaction between themes in the biblical metanarrative and themes within the context of human experience from within historical worldview of the believers, Christian theology is understood in this article as a quest to comprehend divine action revealed in the biblical metanarrative that is applicable in the historical context of believers. It is identifying divine principles for life within the mission of God in the historical context of believers. Thus, Christian theology provides explanation of ongoing divine action in the historical context of believers in the light of the biblical metanarrative. Christian theology serves as a guide for life in partnership with God in His mission in the believers' historical context.

The quest for developing theologies that are contextually meaningful and relevant for African Christians is ongoing. The authors of this article seek to participate in the discourse with the African and global hermeneutical communities in the quest for developing an African Christian theology of the blood of Jesus Christ. The authors draw on ATR, Biblical Theology, and Systematic Theology as it relates to the theme of the blood of Jesus Christ while being mindful of cultural biases. There is no African Christian theology of the blood of Jesus Christ that has been proposed following a scholarly and critical examination as far as these authors are aware.

Therefore, these writers seek to contribute to the treatment of theological anemia in Africa and to contribute to a scholarly and critical examination of the theology of the blood of Jesus Christ. The next section discusses the animal sacrifices in the Old Testament, its roles and purposes as well as the New Testament interpretation of the Old Testament sacrifices in relation to the shedding of the blood of Jesus Christ.

\section{ANIMAL SACRIFICES IN THE OLD TESTAMENT}

The concept of sacredness and deep meaning of ritual is lost in this twenty first century. ${ }^{30}$ Therefore, it is of paramount importance to look at the biblical bases of ritualistic usage of animal blood in order to help the Africa in the twenty first century understand the efficacy of the blood of Jesus Christ.

\section{Blood}

Blood as a term is central in the sacrificial practice of Priesthood as well as its culmination in the sacrifice of Jesus Christ through crucifixion on the cross. The word 70 "blood" linguistically connected with the color "red" 360 times in the Old Testament (henceforth Hebrew Bible). ${ }^{31}$ The Hebrew Bible asserts that life of an organism existed within its blood as shown in Leviticus 19:16

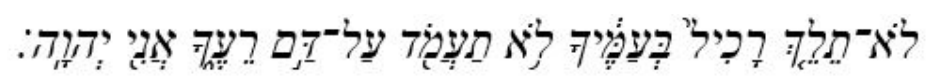

Thou shalt not go up and down as a talebearer among thy people: neither shalt thou stand against the blood of thy neighbour: I am the LORD.

(Lev. 19:16 KJV).

Blood is synonymously used with life. Its first usage was in Genesis 4:10 thus;

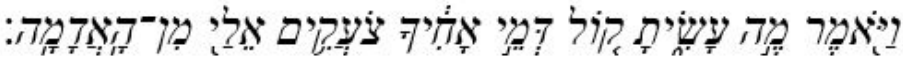

And he said, what hast thou done? The voice of thy brother's blood crieth unto me from the ground. (Gen. 4:10 KJV). And from this time on, blood and life are equated clearly in the post - flood narratives. (cf. Gen. 9:4; Lev. 3:17; 7:26-27; $19: 26) .{ }^{32}$

Blood is also used in the Hebrew Bible as a divinely prescribed means of atonement through animal sacrifice. While carrying out the burnt offering (Lev. 1:3-17; 6:8-13) the blood of an animal either from the herd or the flock or some type of fowl was to be shed by the "offerer" and then sprinkled on the altar by the priest after which the sacrifice was entirely consumed upon the altar as a sacred offering to God. ${ }^{33}$ Since there are several sacrifices offered by the priest in the Hebrew Bible, the one that has to involve "blood" will be henceforth be referred to as "atonement".

The term "atonement" in the Hebrew bible is used to described the effect of the various sacrifices offered in the Hebrew bible that point to the cleansing of sin and reconcile man to God (Ex. 29:36; Lev. 4: 20, 8:14; Num. 5:8; Ezek. 43:20). The efficacy of atonement was thought of as "propitiating" God or "Expatiating" the offenses. The propitiation

\footnotetext{
29 Ibid, 15-16.

30 Elder J. H. Waggoner. Atonement; an Examination of a Remedial System in the Light of Nature and Revelation. (Oakland, Pacific Press, 1884$), 146$

31 T. Desmond Alexander and David W. Baker (eds.) "Blood" in Dictionary of the Old Testament Pentateuch (Downers Grove, Intervarsity Press; 2003), 87-90

32 Ibid, 88.

33 Ibid, 89.
} 
is suggestive that God is alienated by man's sin and requires something to appease His wrath in order to show favor to the sinner. While expatiation presupposes and recognizes that a hindrance to a right relationship has been created by sin, which has to be removed by means of atonement. The word "propitiation" was never used in the Bible, but expatiation has been used in some rear occasions. ${ }^{34}$ Expiation is to remove barriers that sin raised against God. The act of sacrifice should be an endeavor to expiate sin rather than appeasing God's anger towards man. A typical example of appeasing someone is seen in Jacob's presents of gifts to his brother Esau. ${ }^{35}$

\section{Atonement in the Hebrew Bible}

The first reference to atonement in the Bible occurs in Genesis 3:21 when God indirectly provided animal skin to cover Adam and Eve's nakedness. Atonement therefore involves an innocent party taking the punishment that was due to a guilty party. The doctrine of atonement is crucial for the faith of Africans in Judeo-Christian religion due to the ritualistic background of Africans. Thus, the Bible doctrine of atonement is progressive in nature and culminated in the ultimate sacrifice offered by Christ. ${ }^{36}$ Atonement is a process by which all shackles before mankind are removed to reconcile him or her with God. Rituals of expiation and satisfaction are used by a person as a means of re-establishment of or strengthening the religious relationship with the holy/divine being. Atonement is often linked to sacrifice and it is connected to ritual cleansing with moral piety (purity) and religious acceptability. ${ }^{37}$

The term "atonement" in Hebrew is רפיכ "to make" or "to be" one. This indicates the process in the sprinkling of the blood for the sin offerings and this brings reconciliation of man back to God (Lev. 16:5, 10, 15, 21-22). Its cognate derivatives include: רפוכ, which means ransom, bribe (Ex. 21:30; 30:12; 1Sam. 12:3). The word - basically means to purge, Akkadian - kuppuru - "to wipe clean". ${ }^{38}$ Its usage in Leviticus 16:2 indicates that it has altar as its direct object which shows that its meaning is "to purge". 39

\section{Purpose of Atonement}

Atonement in the Hebrew bible as stated in Leviticus 16:20 serves two purposes:

1. The purging of the Sanctuary (the holy Place)

2. The scape goat ritual is released for the purpose of purging the people. (That is the community that surrounded the sanctuary). Both the goat that was slaughtered and its blood sprinkling and the scapegoat were all "sin offering" and both made atonement for the people.

\section{Limitations of the Atonement}

The limitations of the atonement include:

1. Limitation in time; for it applies only to one sin. Every new sin required a new atoning sacrifice.

2. Limitation in content; for not every sin could be atoned for. Deliberate sin's atonement is execution of the sinner.

3. Limited personality; for it applied to the people of Israel. There was no atoning sacrifice for people outside Israelites tribes.

4. Limited to effectiveness; for it did not conquer death. It only conquered some characteristics of death by promising forgiveness. Death therefore is stronger that the atonement of the sin offering. ${ }^{40}$

\section{New Testament Interpretation of Old Testament Animal Sacrifices in Relation to the Shedding of the Blood of Jesus Christ}

The function of the blood in the Hebrew Bible sacrificial system was equivocal, since it was both cleansing and defiling agent. The blood sacrifice purifies the penitent sinners defiled by sin, yet the same blood defiled the sanctuary because it symbolically carried there the sins deposited in the sanctuary atoned for. For this reason, the daily accumulation of sins deposited in the sanctuary necessitated the annual cleansing of the sanctuary on the Day of Atonement. Sins were atoned for and transferred to the sanctuary through the sacrificial system. Such system was divinely established as a means to restore a relationship between God and man broken by sin. The sacrifice of an animal functioned as a substitution for the offender by bearing the punishment of the person to be sacrificed (Ex. 32:30, Isa. 53:6-10). The value of animal sacrifice

\footnotetext{
4 C. L. Mitton “Atonement” in The Interpreter's Dictionary of the Bible, Vol. 1 edited by, George A. Buttrick (New York: Abingdon Press, 1962$), 310$ 
in the Hebrew Bible lies in the fact that they were prophetic, pointing to "the lamb of God, who takes away the sins of the world" (John 1:29). ${ }^{41}$ The rite of the laying on of hands fulfilled a double function. On the one hand, it removed the sin from the guilty person or group and made them clean. On the other hand, it transferred the sin of the offender to the sacrificial animal that in turn carried it to the sanctuary. ${ }^{42}$

All repentant and confessed sins were transferred to an innocent victim by the laying on of hands. Through the sacrificial rites the guilty sinners were forgiven and cleansed, but their sins were not nullified. The sins borne by the sacrificial victim were transferred to the sanctuary either through the ritual of the blood sprinkling in the Holy place or through the eating of the sacrificial flesh by the priest in the sanctuary complex. ${ }^{43}$

Animal sacrifice in the Hebrew Bible from the beginning has to do with the heart of the worshipper and not necessarily about the value of his or her offering. This can be seen in the message of Hosea; "I desire steadfast love and not sacrifice, the knowledge of God rather than burnt offerings" (6:6).

\section{Jesus Christ: The Ultimate Sacrifice}

The Hebrew Bible sacrificial system finds its culmination in the sacrifice of Jesus Christ. The daily sacrifice offered by the Israelites laid the foundation for the coming of Jesus Christ. The arrival of Jesus gave the full significance of the sacrificial system (Heb. 9:11-10:25). Jesus offered himself as the ultimate sacrifice on Mankind's behalf. This is clearly explained by the writer of Hebrew where Jesus is explained to be the final sacrificial lamb whose blood cleanses the sins of sinners once and for all.

\section{The Shedding of Animal Blood and Associated Beliefs in Africa Before the Advent of Missionary Christianity}

The religious beliefs and practices of animal sacrifices in the traditional African context before the advent of the Christian faith from a Euro-American perspective expressed the Africans quest for spiritual power to facilitate their holistic wellbeing in life. Almost all traditional cultures in Africa have beliefs in the concept of destiny which posits that whatever has happened, whatever is happening, and whatever will happen to an individual in future is predestined. This concept is a metaphysical phenomenon that is deeply rooted in the spiritual world. ${ }^{44}$ The traditional African person believes that success in any aspect or endeavor in life is possible only when one relies on a spiritual power. ${ }^{45}$ Therefore sacrifices play an essential part in African religion which aim at establishing and maintaining cordial and intimate relation between human beings and the object of their worship. ${ }^{46}$

T.O. Ebhomienlen and M.O. Idemudia, ${ }^{47}$ and Daniel Olatunji Ayoola, ${ }^{48}$ posit that the purposes and significance of sacrifice in ATR include:

1. Human access to divine power to enable the growth of crops and abundant yield and harvest,

2. Averting devastating effects of the anger of offended deity,

3. The establishment of mystical union with a deity,

4. Communal meals with deity,

5. Propitiation for the forgiveness of sin,

6. Exorcism and purification, and

7. Protection against sickness, enemies, death, good health, long life, peace, prosperity and safety in travelling.

In the African traditional worldview, the invisible spiritual realm of existence is the source of supernatural power. It is assumed that the there is an inherent power in the blood of an animal shed as a sacrifice. Power is sought for temporal utilitarian well-being in the context of uncertainty and fear. The offering of sacrifices, including animal sacrifices, is a means of accessing the supernatural power needed to affect the desired state of holistic well-being in their contextual experiences. Thus, it is understood from the traditional African worldview that power is sought from the spiritual realm as a means of facilitating the holistic well-being of individuals-in-community and/or of the community. This

41 Ibid, 203

42 ibid, 204.

43 Ibid

44 Felix Ayemere Airoboma, “The Concept of Destiny and Its Social Implications Among the Esans" in JORIND 10 (13): 219-226, December, 2012, accessed June 19, 2020. www.transcampus.org/journals; Yusufu Turaki, “Africa Traditional Religious System as Basis of Understanding Christian Spiritual Warfare" accessed June 19, 2020. https://www.lausanne.org/content/west-african-case-study.

45 Samuel O. Onakonvwen, Effective Prayer Guide for African Christians and Pastors (Warri: Soonajane-Ventures, 2016 ), 6.

46 Babalola's article is an evaluative study of the attempt of an African Indigenous Church (AIC), the Cherubim and Seraphim Church, in Nigeria to contextualize the gospel.

47 T.O. Ebhomienlen and M.O. Idemudia, "Sacrifice In Yahwism and African Traditional Religion: The Edo Perspective," in International Journal of Scientific \& Engineering Research Volume 5, Issue 1, January-2014, 364-383.

48 Daniel Olatunji Ayoola, "Revitalization of Orunmila Worship in African Indigenous Religion and Its Challenges to Global Evangelization" in Global Evangelization and the Challenges for Contemporary Church, edited by Michael Adeleke Ogunewu and Adebayo Oladele Odesola, (Ogbomoso: Publishing Unit, The Nigerian Baptist Theological Seminary, 2018), 290. 
understanding has implication for developing a biblical, contextually meaningful and relevant theology that provides explanation concerning divine provisions for meeting the contextual needs of people in their historical context. It is thus argued in this article that the quest for power through the shedding of animal blood as sacrifice to the gods and/ or spirits to address the utilitarian needs of Africans in their traditional African religious worldview has influenced the development of a popular African Christian theology of the blood of Jesus Christ which posits that the shed blood of Jesus Christ has inherent divine power that can be invoked by faith to address the challenges of life that contend with the holistic well-being of human beings.

In view of the foregoing, it is imperative for African Christians to consciously develop a contextual theology that provides a conceptual insight on how God's universal message revealed in the biblical metanarrative adequately addresses the existential needs of Africans in their historical context. God's universal, message the biblical theme of the blood of Jesus Christ, communicates needs to be critically contextualized to address the holistic needs of Africans and to biblically modify their quest for holistic well-being with the aid of the supernatural.

\section{Proposed African Christian Theology of the Blood of Jesus Christ}

This section presents the proposed African Christian theology of the blood of Jesus Christ. It is a theology drawn from a direct epistemological interaction between the biblical doctrine of the blood of Jesus Christ drawn from the biblical narratives and the African traditional conceptual understanding, affective commitment and volitional and vocational practices of animal sacrifices for religious and spiritual purposes.

The proposed African Christian theology of the blood of Jesus Christ posits that: God acts on the basis of the vicarious shedding of the blood of Jesus Christ, the Lamb of God, to forgive sins, incorporate believers into a FatherChild relationship which grants the believer access to a special divine benevolence as a means of experiencing the transformative power of God that guides the believers through life to progressively experience the improvement of their holistic well-being until Jesus Christ returns to reinstate a perfect holistic well-being for God's people. The proposed African Christian theology of the blood of Jesus Christ addresses and transforms the traditional African religious belief which has been incorporated into the contemporary African Christian theology of the blood of Jesus Christ which posits that it is inherent power in the blood rather than the sovereign power of God. It is not inherent divine power in the elemental blood of Jesus Christ that needs to be invoked to address experiential challenges in life. Therefore, there is no need to invoke the blood of Jesus Christ but to trust in God to sovereignly act to address the experiential challenges in life and to facilitate the progressive improvement of the holistic well-being of believers. God in His sovereignty accepts the shedding of the blood of Jesus Christ as a vicarious atonement for sin. It is God by His sovereign power who facilitates the progressive improvement of holistic well-being of believers on earth in spite of the challenges believers face on earth.

\section{CONCLUSION}

This discourse proposes an African Christian theology of the blood of Jesus Christ that is biblical and contextually meaningful and relevant for the orthopraxis of the Christian faith in the African socio-cultural and historical contexts. The shedding of the blood of Jesus Christ is described as the means by which God makes provision for:

1. A vicarious atonement and divine forgiveness of sin.

2. The incorporation of believers into a Father-Child relationship with God.

3. The believers' access to a special divine benevolence. The access to the divine benevolence is a means of experiencing the transformative power of God. The transformative power of God guides believers through life to progressively experience the improvement of their holistic well-being until the return of Jesus Christ when the holistic well-being will be made perfect.

The proposed African Christian theology of the blood of Jesus Christ addresses and eliminates the uncritical integration of the traditional African worldview that suggests the presence of inherent power in the elemental blood of Jesus Christ that is invoked to initiate divine action for the utilitarian benefits of man. The blood of Jesus Christ serves a vicarious purpose to atone for sin as a basis for divine forgiveness. The divine forgiveness makes it possible to be in a personal relationship with God. Personal relationship with God provides direct access to divine benevolence which progressively transforms the challenges of life for the progressive improvement of the holistic wellbeing of the child of God. The progressive transformation of challenges which facilitates the progressive improvement of the holistic well-being of the child of God forms the basis for having hope for the future perfect state of holistic wellbeing divinely promised as recorded in the biblical metanarrative. 


\section{BIBLIOGRAPHY}

Airoboma, Felix Ayemere. "The Concept of Destiny and Its Social Implications among the Esans" in JORIND in www.transcampus.org/journals, 10 (13): 219-226, December, 2012.

Akande, Adelani. "The Role of Theological Education in Contextualisation" in Indigenization of the Church in Africa: The Nigerian Situation, edited by A. A. Akande, M. Audi, and O. B. Oladejo. Ogbomoso: NBTS, 2012.

"Atonement" in Dictionary of the Old Testament Pentateuch, edited by Alexander, T. Desmond and David W. Baker, Downers Grove: Intervarsity Press; 2003.

"Atonement" in Merriam-Webster's Encyclopedia of World Religions, edited by Wendy Doniger. Springfield, Massachusetts: Merriam-Webster, Incorporated, 1999.

Audi, Moses. "Living With Inherited Denominations: An African Perspective," in Indigenization of the Church in Africa: The Nigerian Situation, edited by A. A. Akande, M. Audi, and O. B. Oladejo. Ogbomoso: NBTS, 2012.

Ayoola, Daniel Olatunji, "Revitalization of Orunmila Worship in African Indigenous Religion and Its Challenges to Global Evangelization" in Global Evangelization and the Challenges for Contemporary Church, edited by Michael Adeleke Ogunewu and Adebayo Oladele Odesola. Ogbomoso: Publishing Unit, The Nigerian Baptist Theological Seminary, 2018.

Babalola, Emmanuel, “'Pauline Christology’ in Colossians 1:15-20 and its implication of Africanness of Cherubim and Seraphim Church's Angelology" in Journal of Studies in Social Sciences and Humanities in http://www.jssshonline.com/volume2, Number 2, 2016, 61-71.

"Blood" in Dictionary of the Old Testament Pentateuch, edited by Alexander, T. Desmond and David W. Baker. Downers Grove, Intervarsity Press; 2003.

Columbia University Mailman School of Public Health, "Content Analysis" [Retrieved from www.mailman.columbia.edu.

Ebhomienlen, T.O. and M.O. Idemudia, "Sacrifice In Yahwism and African Traditional Religion: The Edo Perspective," in International Journal of Scientific \& Engineering Research, Volume 5, Issue 1, January-2014, 364-383.

Hiebert, Paul G., "The Gospel in Human Contexts: Changing Perceptions of Contextualization"" in Missionshift: Global Mission Issues in the Third Millenium," edited by David J. Hesselgrave and Ed Stetzer. Nashville, Tennessee: B \& H Publishing Group, 2010.

Kato, Byang, Theological Pitfalls in Africa. Kenya: Evangel Publishing House, 1975. . Biblical Christianity in Africa, Achimota: Africa Christian Press, 1985.

Kunhiyop, Samuel Waje, African Christian Theology. Nairobi: Hippo Books, 2012.

Mayring, Philipp, "Qualitative Content Analysis” in Forum: Qualitative Social Research, 1:2, Art 20, June, 2000 Accessed 5, 2019 from www.qualitative-research.net

Mitton, C. L., "Atonement" in the Interpreter's Dictionary of the Bible. Vol. 1 ed. George A. Buttrick, New York: Abingdon Press, 1962.

Nihinlola, Ezekiel Emiola, "Human Being, Being Human: Theological Anthropology in the African Context," Ogbomoso: The Publishing Unit, Nigerian Baptist Theological Seminary, 2018.

Ojo, Ola Jonathan, "Biblical Atonement and its Significance for the Faith of Africans in the $21{ }^{\text {st }}$ Century Ministry" in the Present State and the Future of Biblical Studies in Africa, Essay in Honour of Samuel Oyinloye Abogunrin edited by J. D. Gwamna et al, Ibadan: Zenith Book House ltd, 2017.

Onakonvwen, Samuel O., Effective Prayer Guide for African Christians and Pastors, Warri, Nigeria: SoonajaneVentures, 2016.

Palmer, Timothy, Christian Theology in an African Context. Bukuru: African Christian Textbooks, 2015.

"Religious Syncretism” in Encyclopedia Britannica. Accessed June19, 2019. Retrieved from www.britannica.com/topic/religious-syncretis

Richards, Larry, Every Teaching of Jesus in the Bible, Nashville: Thomas Nelson Publishers, 2001.

Tambiyi, Gideon Yohanna, The African Church Under Fire: Problems and Prospects. Kaduna: Tubase Prints and Publishing, 2014.

Tienou, Tite and Paul G. Hiebert, "Missional Theology" in The Gospel in Human Contexts: Anthropological Explorations for Contemporary Missions edited by Paul G. Heibert, Grand Rapids, Michigan: Baker Academic, 2009.

Turaki, Yusufu. “Africa Traditional Religious System as Basis of Understanding Christian Spiritual

Warfare" Retrieved from https://www.lausanne.org/content/west-african-case-study.

Waggoner, Elder J. H. Atonement: an Examination of a Remedial System in the Light of Nature and Revelation. Oakland, Pacific Press, 1884.

Wright, Christopher J. H., The Mission of God: A Biblical Theology of the Church's Mission. Grand Rapids, Michigan: Zondervan, 2010. 